5 Bhugra D, Leff J, Mallett R, Der G, Corridan B, Rudge S. Incidence and outcome of schizophrenia in whites, African-Caribbeans and Asians in London. Psychol Med 1997;27:791-8.

6 McKenzie K, Van Os J, Fahy T, Jones P, Harvey I, Toone B, et al. Psychosis with good prognosis in Afro-Caribbean people now living in the United Kingdom. BMJ 1995;311:1325-8.

7 Hutchinson G, Takei N, Fahy TA, Bhugra D, Gilvarry C, Moran P, et al. Morbid risk of schizophrenia in first-degree relatives of white and African-Caribbean patients with psychosis. Br J Psychiatry 1996;169: $776-80$.

8 Hutchinson G, Takei N, Bhugra D, Fahy TA, Gilvarry C, Mallett R, et al. Increased rate of psychosis among African-Caribbeans in Britain is not due to an excess of pregnancy and birth complications. Br J Psychiatry 1997:171:145-7.

9 Hutchinson G, Mallett R, Fletcher H. Are the increased rates of psychosis reported for the population of Caribbean origin in Britain an urban effect? Int Rev Psychiatry 1999;11:122-8.

10 Sharpley MS, Hutchinson G, Murray RM, McKenzie K. Understanding the excess of psychosis among the African-Caribbean population in England: review of current hypotheses. Br J Psychiatry 2001;178(suppl 40):60-8.

11 Halpern D. Minorities and mental health. Soc Sci Med 1993;36:597-607.

12 Cochrane R, Bal SS. Ethnic density is unrelated to incidence of schizophrenia. Br J Psychiatry 1988;153:363-6.

13 McGuffin P, Farmer A, Harvey I. A polydiagnostic application of operational criteria in studies of psychotic illness. Development and reliability of the OPCRIT system. Arch Gen Psychiatry 1991;48:764-70.
14 Wing JK, Cooper JE, Sartorius N. The measurement and classification of psychiatric symptoms. London: Cambridge University Press, 1974.

15 Williams J, Farmer AE, Arkenheil M, Kaufmann CA, McGuffin P. A multicentre inter-rater reliability study using the OPCRIT computerized diagnostic system. Psychol Med 1996;26:775-83.

16 Castle D, Wessely S, Der G, Murray RM. The incidence of operationally defined schizophrenia in Camberwell, 1965-84. Br J Psychiatry 1991;159:790-4.

17 Office of Population Census and Surveys Population Estimates Unit. 1991 census, Local base statistics. London: Office for National Statistics, 1991.

18 London Research Centre. Round projections and methodology. London: London Research Centre, 1997.

19 Department of the Environment. Index of local conditions. London: Office for National Statistics, 1991

20 Rabkin J. Ethnic density and psychiatric hospitalization: hazards of minority status Am J Psychiatry 1979;136:1562-6.

21 Murphy HBM. Migration and the major mental disorders: a reappraisal. In: Kantor M, ed. Proceedings of the fifth annual conference on community mental health research. Springfield, IL: Charles C Thomas, 1965:5-28.

22 Williams D. Racism and health: a research agenda. Ethn Dis 1996;6:1-6.

23 King G, Williams DR. Race and health a multi-dimensional approach to African-American health. In: Amik BC III, Levins S, Tarlov AR, Chapman Walsh D, eds. Society and health. New York: Oxford University Press, 1995:93-130.

(Accepted 29 August 2001)

\title{
Prescriptions for antiulcer drugs in Australia: volume, trends, and costs
}

\author{
Johanna I Westbrook, Anne E Duggan, Jean H McIntosh
}

Centre for Health Informatics, University of New South Wales, Kensington 2052, NSW, Australia Johanna I Westbrook associate professor, medical informatics

Department of Gastroenterology, John Hunter Hospital, New Lambton Heights 2305, NSW, Australia

Anne E Duggan staff specialist

School of Health Information Management,

University of

Sydney, Lidcombe

1825 , NSW,

Australia

Jean H McIntosh

research assistant

Correspondence to: J I Westbrook

J.Westbrook@unsw.

edu.au

BMJ 2001;323:1338-9
$\mathrm{H}_{2}$ receptor antagonists and proton pump inhibitors have markedly changed the management of peptic ulcer and gastro-oesophageal reflux disease; they have also changed the profile of national drug budgets. Antiulcer drugs have retained the leading position in drug sales worldwide: sales of antiulcer drugs were valued at \$US12.9 billion (£8.6bn) in 1998 and were increasing at $3 \%$ a year. ${ }^{1}$

Since 1992 the Australian government's pharmaceutical benefits scheme has required prescribers of proton pump inhibitors to certify the presence of peptic ulcer disease or ulcerating oesophagitis (confirmed by endoscopy, radiography, or surgery) and refractory to treatment with other drugs, scleroderma oesophagus, or Zollinger-Ellison syndrome. The aim of this study was to assess how these restrictions have affected prescribing of antiulcer drugs.

\section{Participants, methods, and results}

We analysed data from the pharmaceutical benefits scheme on the number of prescriptions for $\mathrm{H}_{2}$ receptor antagonists, proton pump inhibitors, and cytoprotectant agents for the financial years 1992-3 to 1996-7 and 1999. Data on misoprostol and treatments to eradicate Helicobacter pylori were available only for 1999.

In 1999 antiulcer drugs made up $6.1 \%$ of all prescriptions dispensed. They were the second most costly group of drugs to the government, consuming $11.1 \%$ of the total pharmaceutical benefits scheme budget (table). Ranitidine, famotidine, nizatidine, omeprazole, and lansoprazole were all among the 100 drugs most often prescribed, and, with pantoprazole, were among the 100 most costly drugs to the government. Ranitidine was the third most commonly prescribed, and omeprazole was the second most costly. The total number of prescriptions for proton pump inhibitors was only half $(51 \%)$ that for the $\mathrm{H}_{2}$ receptor antagonists, but proton pump inhibitors were 2.4 times more costly. $H$ pylori eradication treatments made up only $1.3 \%$ of all prescriptions for antiulcer drugs.

Between 1992-3 and 1999 total prescriptions for $\mathrm{H}_{2}$ receptor antagonists, proton pump inhibitors, and cytoprotectant agents increased by $109 \%$-increases of $51 \%$ for $\mathrm{H}_{2}$ receptor antagonists and $1228 \%$ for proton pump inhibitors and a decrease of $84 \%$ for cytoprotectants. Prescriptions for proton pump inhibitors increased by $40 \%$ between 1995- 6 and 1996-7 and by $43 \%$ between 1996-7 and 1999. Prescriptions for $\mathrm{H}_{2}$ receptor antagonists increased by 3\% between 1995-6 and 1996-7 and decreased by 4\% between 1996-7 and 1999. Proton pump inhibitors have continued to make up an increasing proportion of total antiulcer drugs prescribed $(13 \%$ in $1994-5,20 \%$ in $1995-6,25 \%$ in 1996-7, and $34 \%$ in 1999).

\section{Comment}

The proportion of proton pump inhibitors prescribed relative to $\mathrm{H}_{2}$ receptor antagonists is at odds with the guidelines for the Australian pharmaceutical benefits scheme and with data on the epidemiology of refractory oesophagitis. Despite restrictions, proton pump inhibitors accounted for 34\% of prescriptions for antiulcer drugs and for $51 \%$ of government expenditure on antiulcer drugs in 1999. Around 7-8\% of consultations with general practitioners are for gastrointestinal problems, and this proportion did not change between 1992 and 1999. ${ }^{2}$ Australians seem to consult at higher rates for gastrointestinal symptoms than do other nationalities. ${ }^{3}$ The continued rise in the 
Prescriptions for antiulcer drugs in Australia, 1999. Number, cost, and ranking for frequency and cost to the government pharmaceutical benefits scheme

\begin{tabular}{|c|c|c|c|c|c|c|c|}
\hline & $\begin{array}{c}\text { No of } \\
\text { prescriptions } \\
\text { dispensed }\end{array}$ & $\begin{array}{l}\text { Rank among } \\
\text { top } 100 \text { drugs } \\
\text { dispensed }\end{array}$ & $\begin{array}{l}\text { Cost to } \\
\text { government } \\
(\$ A)\end{array}$ & $\begin{array}{c}\text { Rank among } 100 \\
\text { drugs most costly } \\
\text { to government }\end{array}$ & $\begin{array}{c}\text { Average } \\
\text { price }(\$ A)\end{array}$ & $\begin{array}{c}\text { Total cost } \\
\text { (market } \\
\text { value) }\end{array}$ & $\begin{array}{l}\% \text { of total } \\
\text { cost paid by } \\
\text { government }\end{array}$ \\
\hline \multicolumn{8}{|l|}{$\mathrm{H}_{2}$ receptor antagonists: } \\
\hline Cimetidine & 208162 & Not ranked & 4942504 & Not ranked & 29.60 & 5893232 & 84 \\
\hline Ranitidine & 3602179 & 3 & 63679869 & 5 & 23.78 & 85642291 & 74 \\
\hline Famotidine & 1082206 & 36 & 18879948 & 41 & 24.28 & 26271972 & 72 \\
\hline Nizatidine & 421797 & 91 & 7492537 & 89 & 24.27 & 10236216 & 73 \\
\hline \multicolumn{8}{|l|}{ Proton pump inhibitors: } \\
\hline Omeprazole & 2025688 & 12 & 170605379 & 2 & 91.81 & 185986386 & 92 \\
\hline Lansoprazole & 465666 & 85 & 39308831 & 15 & 92.98 & 43299039 & 91 \\
\hline Pantoprazole & 208678 & Not ranked & 18514652 & 44 & 97.12 & 20267050 & 91 \\
\hline \multicolumn{8}{|l|}{ Prostaglandin analogue: } \\
\hline Misoprostol & 20004 & Not ranked & 905069 & Not ranked & 50.53 & 1010762 & 90 \\
\hline \multicolumn{8}{|l|}{ Cytoprotectant agents: } \\
\hline Bismuth & 3495 & Not ranked & 75157 & Not ranked & 28.64 & 100086 & 75 \\
\hline Sucralfate & 17803 & Not ranked & 313572 & Not ranked & 23.05 & 410308 & 76 \\
\hline \multicolumn{8}{|l|}{ Helicobacter pylori eradication treatment: } \\
\hline Bismuth-metronidazole-tetracycline & 7448 & Not ranked & 408466 & Not ranked & 64.87 & 483118 & 85 \\
\hline Omeprazole-clarithromycin-amoxicillin & 92945 & Not ranked & 8769326 & 78 & 104.66 & 9727314 & 90 \\
\hline Ranitidine-bismuth-clarithromycin-amoxicillin & 2378 & Not ranked & 217014 & Not ranked & 101.30 & 240820 & 90 \\
\hline Omeprazole-metronidazole-amoxicillin & 5527 & Not ranked & 441656 & Not ranked & 90.60 & 500768 & 88 \\
\hline Total for antiulcer treatment & 8143973 & 7 & 333648911 & 2 & & 390069362 & 86 \\
\hline
\end{tabular}

number of prescriptions for proton pump inhibitors, combined with evidence of inappropriate use, ${ }^{4}$ suggests that the restrictions have had a limited impact on prescribing behaviour.

In contrast, despite the well established benefits of eradication of $H$ pylori in the management of peptic ulcer disease, only $1.3 \%$ of total prescriptions in 1999 were for treatments to eradicate $H$ pylori.

The decline in the number of prescriptions for $\mathrm{H}_{2}$ receptor antagonists is consistent with experience in the United States and Britain. The National Institute for Clinical Excellence has issued guidelines that are expected to reduce prescriptions for proton pump inhibitors by 15\% in England and Wales. ${ }^{5}$ The Australian experience provides some much needed comparative data for future evaluations of the impact of these guidelines.
Contributors: JIW designed the study, undertook analyses, and participated in writing the paper. AED participated in analysis and had a substantial role in writing the paper. JHM extracted drug data, assisted in analysis, and was involved in writing the paper. JIW and AED are joint guarantors of the paper.

Funding: None.

Competing interests: None declared.

1 Latner A. The top 200 drugs. Pharmacy Times 2000. www. pharmacytimes.com/top200.html (accessed 31 Jan 2000).

2 Britt H, Sayer G, Miller G, Scahill S, Horn F, Bhasale A, et al. General practice activity in Australia 1998-99. Canberra: Australian Institute of Health and Welfare, 1999

3 Westbrook J, McIntosh J, Talley N. Factors associated with consulting medical and non-medical health practitioners for dyspepsia: an Australian population-based study. Aliment Pharmacol Ther 2000;14:1581-8.

4 McManus P, Marley J, Birkett D, Lindner J. Compliance with restrictions on the subsidized use of proton pump inhibitors in Australia. $\mathrm{Br} J \mathrm{Clin}$ Pharmacol 1998:46:409-11.

5 National Institute for Clinical Excellence. Guidance on the use of proton pump inhibitors in the treatment of dyspepsia. London: NICE, 2000.

(Accepted 29 August 2001)

\section{A medical mishap}

\section{A poor historian}

A retired polysymptomatic man attended surgery with his wife describing "adrenaline rushes," 15 minute periods of flushing, palpitations, and overwhelming anxiety. These had been occurring for many years but with increasing frequency. His wife attributed this to his "nerves," something he strongly denied. A brief scan through the man's notes gave the impression of a frequent attender with a history of anxiety disorder, hypertension, hyperlipidaemia, and arrhythmia, with numerous outpatient visits and cardiac investigations to his name.

He requested an adrenal scan to look for the source of all his adrenaline. "Extremely unlikely to yield any valuable

information," I informed him, opting instead for a cardiology referral for consideration of an event recorder and adjustment of his antiarrhythmia treatment.

Fortunately, the cardiologist was alert, and two tests for urinary catecholamine concentration have revealed phaeochromocytoma, with a pending MIGB (131I-metaiodobenzylguanidine) scan to guide further management.

What have I learnt from this? Firstly, history taking, the first clinical skill learnt at medical school, underpins all diagnoses. In among this patient's numerous complaints lay a textbook description of a period of crisis from a sympathetic tumour. The poor historian was not the patient but the doctor, for my inability to interpret the information presented in an unbiased way.

Secondly, although common things are common, rarities do occur and are equally likely to arise in a patient previously labelled with a psychiatric disorder.

And finally, although prior knowledge of a patient's history can guide the consultation, it may also prejudice its outcome.

Matthew Bull general practitioner registrar, Tunbridge Wells 